\title{
Active migration of wild Atlantic salmon Salmo salar smolt through a coastal embayment
}

\author{
Richard D. Hedger ${ }^{1, *}$, François Martin ${ }^{1}$, Daniel Hatin ${ }^{2}$, François Caron ${ }^{3}$, \\ Fred G. Whoriskey ${ }^{4}$, Julian J. Dodson ${ }^{1}$ \\ ${ }^{1}$ Département de Biologie, Université Laval, Québec, Québec G1K 7P4, Canada \\ ${ }^{2}$ Direction de la Recherche sur la Faune, Ministère des Ressources Naturelles et de la Faune du Québec, Longueil, \\ Québec J4K 2T5, Canada \\ ${ }^{3}$ Direction de la Recherche sur la Faune, Ministère des Ressources Naturelles et de la Faune du Québec, Jonquière, \\ Québec G7X 8L6, Canada \\ ${ }^{4}$ Atlantic Salmon Federation, PO Box 5200, St. Andrews, New Brunswick E5B 3S8, Canada
}

\begin{abstract}
Migration patterns of wild Atlantic salmon Salmo salar smolt were examined in a coastal embayment in the Gaspé peninsula of Québec, Canada. Twenty-four smolt in 2005 and 30 in 2006 were tagged with coded ultrasonic transmitters, and their migration throughout the bay was monitored using an array of fixed VR2 hydrophone receivers. Migration patterns were complex, with some smolt taking a direct route through the coastal embayment and others repeatedly changing direction over short spatial and temporal scales. Migration was mainly an active process with an overall outward (seaward) migration in the face of an inward residual circulation. Swimming direction was mainly outward during nocturnal inflowing currents but was more dispersed during daytime and nocturnal outflowing currents; swimming speed was greater during daytime than during nighttime. This pattern was consistent with smolt migrating offshore nocturnally and using daytime for prey detection and predator avoidance. Salinity had a strong effect: exposure to more saline waters caused increased swimming speeds. These observations are consistent with the hypothesis that smolt exploit an innate compass to maintain a preferred bearing and that the speed and direction of swimming is controlled by salinity and the diurnal cycle.
\end{abstract}

KEY WORDS: Salmon smolt migration - Current flow · Salinity gradient · Orientation · Diurnal migration

Resale or republication not permitted without written consent of the publisher

\section{INTRODUCTION}

The migration of salmonid smolt from the freshwater habitat, through the surface waters of estuaries and into the pelagic marine environment as part of their anadromous lifecycle is a mixture of passive and active processes (reviewed by Holm et al. 2003). Water flow tends to passively displace the position of any individual within the water body. However, salmonid smolt may actively influence the rate at which they move by swimming (Finstad et al. 2005). Some authors have found distinct periodicities, with smolt migrating seaward during the ebb tide, suggesting a passive component to the migration (McCleave 1978, Tytler et al. 1978, Aprahamian \& Jones 1997, Lacroix et al. 2005). Other authors have found evidence of active migration, such as smolt moving against tides (Moore et al. 1998) or independently of current direction (Thorstad et al. 2004, Økland et al. 2006).

Given that smolt mainly migrate though the uppermost layers of estuarine and marine water bodies (Dutil \& Coutu 1988, Reddin \& Short 1991, Shelton et al. 1997, Holm et al. 2000, Rikardsen et al. 2004, Reddin et al. 2006), conditions in this layer are likely to have the most effect on the direction and speed of migrating smolt. Most research has focussed on the influence of current flows and salinity gradients (Holm et al. 1982, Moser et al. 1991, Thorstad et al. 2004). Other mechanisms, such as celestial or magnetic cues (Taylor 1986) or changes in water chemical composition as detected by olfaction (Stabell 1984), may also play a role. 
Smolt migration patterns and their underlying mechanisms have come under increasing scrutiny, particularly with the advent of small ultrasonic transmitters, which allow accurate monitoring of smolt positions (Voegeli et al. 1998) either through the use of an array of fixed hydrophones (Finstad et al. 2005, Lacroix et al. 2005) or by the use of mobile tracking (McCleave 1978, Tytler et al. 1978, Økland et al. 2006). Telemetry studies have used both wild and hatchery-reared smolt. This distinction is important as hatchery-reared smolt may show different behaviours, and thus different migration patterns, compared to wild smolt (Tytler et al. 1978, McCormick et al. 1998).

There is increasing concern that greater rates of marine mortality documented among Atlantic salmon over the past decade may be largely incurred in the near-shore coastal zone, where smolt may be exposed for the first time to a large field of predators (Blackwell \& Juanes 1998, Dieperink et al. 2002). It is thus imperative to understand the mechanisms employed by Atlantic salmon during this early stage in the marine migration and the influence of environmental factors on migratory patterns.

In the present study, empirical statistical modelling was used to determine the influence of environmental properties on the spatial and temporal migration patterns of wild Atlantic salmon smolt with the objective of determining the relative importance of passive and active processes underlying the migration. We used Gaspé Bay, a coastal embayment in Québec, Canada, as a study area. In particular, analyses focussed on the interaction between smolt movements and surface currents, salinity gradients and celestial effects at the smallest spatial scales possible. Detailed measurements of salinity and current flows were made. From the spatial and temporal patterns that were found, a methodology was developed that enabled analysis of their effects on smolt migration through a dense array of fixed hydrophones in this embayment.

\section{MATERIALS AND METHODS}

Study area. Gaspé Bay is a coastal embayment on the northeastern coast of the Gaspé peninsula in Québec, Canada $\left(48.85^{\circ} \mathrm{N}, 64.45^{\circ} \mathrm{W}\right)$ (Fig. 1). The bay is composed of 2 distinct areas: a partially enclosed inner bay and an open outer bay. The inner bay is wide $(>4 \mathrm{~km}$ ) and shallow (maximum depth of $25 \mathrm{~m}$ ) relative to its length (ca. $10 \mathrm{~km}$ ). It is separated from the outer bay by a sandbar (Sandy Beach), which is submersed at high tide. There is a relatively deep channel in the north (ca. $1 \mathrm{~km}$ wide and $20 \mathrm{~m}$ deep) where the bulk of the interchange of water between the inner and outer bays occurs. The bay receives freshwater input from the York River and Dartmouth River in the inner bay, and the St. Jean River in the outer bay. The bay is typically vertically stratified in summer, with a surface layer of relatively warm and fresh water of riverine origin overlying a layer of colder saline water of maritime origin (Carrière 1973, Koutitonsky et al. 2001). Water circulation is driven by tides (Godin 1988), wind (Koutitonsky \& Bugden 1991), pressure gradients and river flows. Patterns of circulation are complex (Pettigrew et al. 1991), suggesting that tidally driven surface currents are strongly modified by other forces. In particular, the role of wind forcing within the inner bay may be more pronounced than in most estuaries due to the sandbar that partially obstructs tidal flows.

For the purpose of this study, smolt movements within the bay are defined as being 'outward' (directed towards the sea in the east) or 'inward' (directed towards the land to the southwest and west).

Smolt capture, tagging and tracking. Patterns of smolt migration were determined by acoustic telemetry. Wild Atlantic salmon smolt were collected $16 \mathrm{~km}$ upstream from the river mouth in the York River with a Pennsylvania trap between 30 May and 10 June 2005 (5163 smolt captured) and between 20 May and 5 June

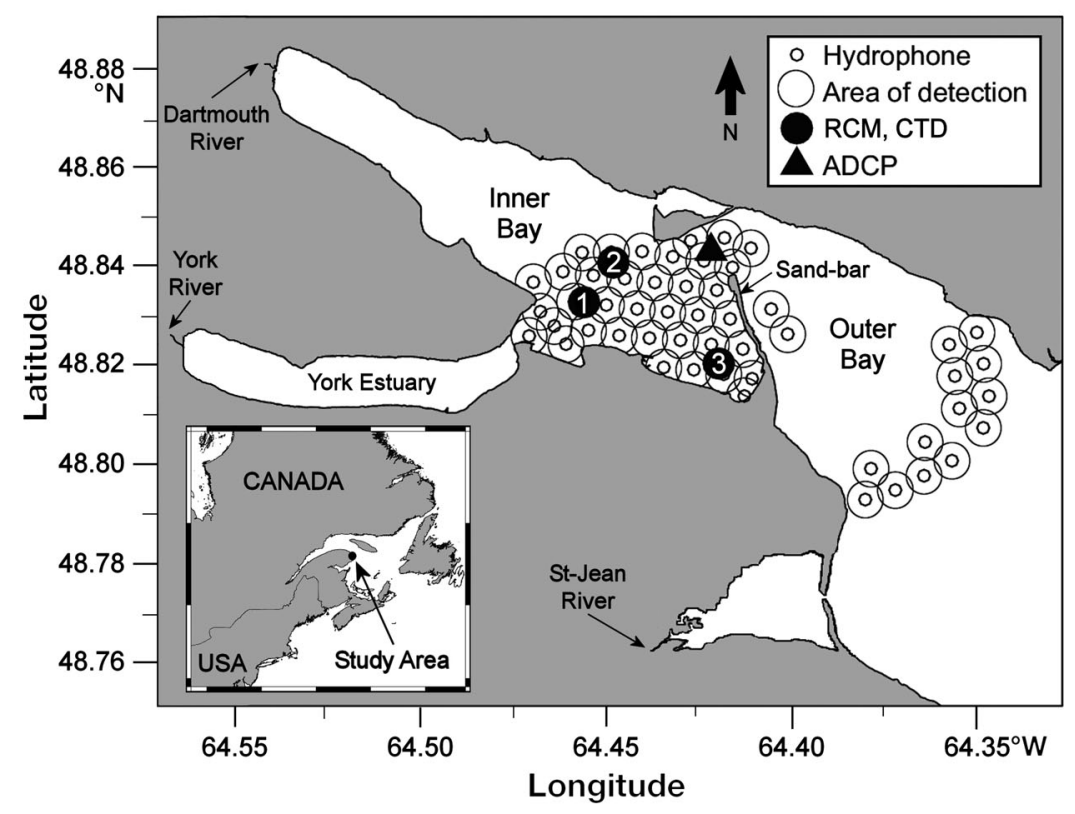

Fig. 1. Study area on the northeastern coast of the Gaspé peninsula in Québec, Canada, showing position of hydrophones, acoustic Doppler current profiler (ADCP), recording current meters (RCMs), and CTDs. The detection range around each hydrophone is shown with a radius of $400 \mathrm{~m}$ 
2006 (2790 smolt captured). Of these, the largest smolt were selected to permit transmitter implantation with minimum mortality risk. Migration patterns were studied with 24 and 30 smolt tagged in 2005 and 2006, respectively, using coded short-term internal transmitters (Vemco, V9-6L model, $9 \times 20 \mathrm{~mm}, 3.3 \mathrm{~g}$ in air, 20 to $50 \mathrm{~s}$ burst rate, $69 \mathrm{kHz}$ frequency, $53 \mathrm{~d}$ lifespan). Mean fork length and weight of tagged smolt were $152 \mathrm{~mm}$ (range 142 to 172 ) and $31.2 \mathrm{~g}$ (range 24.6 to 44.1 ) in 2005 and $152 \mathrm{~mm}$ (range 142 to 177 ) and $31.5 \mathrm{~g}$ (range 27.1 to 43.4 ) in 2006. Transmitter weight was a relatively small proportion of fish weight (mean 10.25\%, range 7.47 to $13.41 \%$ ). A standard surgery procedure was used for internal implantation of the transmitters (Summerfelt \& Smith 1990). All manipulations were conducted daily from 31 May to 10 June 2005 and from 25 May to 4 June 2006 at the same site located $16 \mathrm{~km}$ upstream.

Migration of transmitter-tagged smolt was monitored in the inner and outer bay by an array of 35 and 53 fixed hydrophones (Vemco, VR2 model) in 2005 and 2006, respectively (Fig. 1). In the inner bay, hydrophones were moored on a grid shaped along transects to ensure complete spatial coverage. Transmitter detection range varied between 200 and $700 \mathrm{~m}$, but was mainly 300 to $400 \mathrm{~m}$. Based on this information, the interval between transects and hydrophones on a given transect was $800 \mathrm{~m}$ in 2005 and $700 \mathrm{~m}$ in 2006. To verify that smolt leaving the inner bay continued their migration through the outer bay, a linear array of hydrophones was moored across the outer bay within a distance of $10 \mathrm{~km}$ of the inner bay (Fig. 1).

Given that smolt positions were interpolated from measurements made at the hydrophones, it was necessary to determine the accuracy of the interpolation. This was done by simulating smolt movements through the hydrophone array using 3 transits ( 4 to $5 \mathrm{~h}$ ) made with a transmitter attached to the outside of a boat below the water. Transits were conducted in areas encompassing the most smolt movements. GPS coordinates of the boat transmitter were obtained at every $20 \mathrm{~m}$ to compare observed positions to interpolated positions based on the moored hydrophone recording data.

Analysis of the telemetry data. The dense array of hydrophones in the inner bay enabled smolt positions to be interpolated at a fine spatial scale. Smolt positions were estimated using a running-line smoother plus linear interpolation (Becker et al. 1988). For each smolt, the running-line smoother $(\operatorname{span}=0.05)$ was fitted to the detections from the hydrophone array, separately establishing the relationship between easting and northing as a function of time. Linear interpolation was then used to determine the position of the smolt at 10 min intervals throughout its detection period in the hydrophone array. This approach differed from the more commonly used weighted-mean approach (Klimley et al. 2001, Simpfendorfer et al. 2002), which was found to provide physically unrealistic velocity estimates. The estimated smolt positions should be viewed as a centre of activity of the smolt rather than the actual position (the same rationale as that of the weightedmean approach). For comparison, smolt positions were also interpolated using the weighted-mean approach.

Characterization of the physical habitat. Tidal elevation was predicted using the WTides software package (www.wtides.com). The accuracy of this prediction for this bay was verified by comparing predicted values with observed values from a small boat harbour in the southwest of the inner bay in 2005 . Wind data were obtained from an onsite Vantage Pro2 anemometer (Davis Instruments), which provided a continuous record at 10 min intervals.

Data on surface currents and salinity were obtained during 2 sampling campaigns: (1) a preliminary campaign in 2005 that provided a comprehensive spatial coverage but limited temporal coverage; and (2) a more detailed campaign in 2006 that provided a complete temporal coverage (i.e. measurements were made throughout the period when smolt were migrating) while maintaining some element of spatial coverage.

In the preliminary sampling campaign of 2005, current flow was determined by 105 Lagrangian buoys, released at 13 stations throughout the inner bay between 28 May and 18 June 2005 during both ebb and flood tides and under a variety of wind conditions. A GPS mounted on each buoy determined its position at 5 min intervals. Typically, 2 buoys were released at a time, and were left in the bay for 1 to $2 \mathrm{~h}$. Surface salinity (practical salinity unit, PSU) was determined at 71 stations throughout the inner and outer bay by a SEACAT Profiler CTD data logger (SeaBird Electronics).

In the campaign of 2006, current flow was determined by instruments sited at fixed positions within the bay - an acoustic Doppler current profiler (ADCP) (Ocean Instruments) and 3 recording current meters (RCMs) (AANDERAA). The ADCP was sited on the bed of the channel connecting the inner to the outer bay (Fig. 1). It measured horizontal velocity at $30 \mathrm{~min}$ intervals along a vertical profile in a series of layers. Current velocity measurements from the layer centred at a depth of $2.7 \mathrm{~m}$ (from 0.46 to $4.94 \mathrm{~m}$ below the surface) were used for analysis because this was the depth believed to be occupied by migrating smolt. The RCMs were positioned $1 \mathrm{~m}$ beneath the surface at sites around the inner bay using moored buoys. A $1 \mathrm{~m}$ depth was chosen because it was near enough to the surface that the near surface flows affecting smolt migration 
could be measured, but was deep enough that estimates of current speed would not be influenced by surface waves (Sherwin 1988). Surface salinity was measured at $10 \mathrm{~min}$ intervals throughout the period of the smolt migration by SEACAT Profiler CTD data loggers fixed to the RCMs.

Spatial heterogeneity of current flow was determined by estimating the correlation of current speed and the angular deviation of current direction as a function of distance using (1) the displacement of the pairs of buoys during 2005 and (2) the fixed current instruments (the ADCP and the RCMs) deployed in 2006 (see Batschelet 1965). Autocorrelation functions were applied to the predicted tidal elevation and the measurements of current flow and salinity from the data of 2006 to determine (1) the existence of temporal periodicity and (2) the relative strength of the temporal dependence.

Analysis of smolt migration and relationships with the physical habitat. Smolt migration within the bay was analyzed using a 2-tier method: (1) synoptic patterns of migration were examined using all smolt data (2005 and 2006); and (2) the relationship between smolt movements and properties of the physical environment was then examined using a subset of the data from 2006 (for which there were more environmental data).

Synoptic patterns of smolt migration were examined to determine how they differed between the inner and outer bays, between the years, and according to smolt size. Comparison of centre-of-activity smolt velocities between the inner and outer bay was not possible because centres of activity could not be estimated in the outer bay (due to the sparseness of the hydrophone array). Therefore, a direct-line ground speed was determined for each smolt in each of the inner and the outer bays. This speed was the Euclidean distance between the points of entrance and exit of the area encompassed by the hydrophone array (in the inner and outer bay) over the time period between entrance and exit.

The relationship between smolt migration and properties directly affecting the smolt was determined when smolt were in proximity (a range of $400 \mathrm{~m}$ or less) to the fixed current instruments and the CTD dataloggers for the 2006 dataset. This range was determined empirically. Smolt swimming velocity was estimated at 10 min intervals by calculating the difference between current velocity and smolt ground velocity (smolt ground velocity being defined as smolt displacement over time, regardless of the extent to which this displacement was active or passive). Given the reliance of these calculations upon the measurements of current velocity, it was only possible to estimate smolt swimming velocity in the proximity of the ADCP and
RCMs 1 and 3 (the speedometer in RCM 2 failed during the experiment). From smolt swimming velocity, direction and speed were estimated. A comparison was then made of smolt swimming patterns (both direction and speed) under differing conditions: (1) current direction and presence/absence of daylight, (2) solar azimuth, and (3) salinity gradient. Analysis of the effect of current direction and presence/absence of daylight was determined for all smolt in proximity to the fixed instruments (ADCP, RCMs 1 and 3) using 4 categories: inflowing current during nighttime, outflowing current during nighttime, inflowing current during daytime, and outflowing current during daytime. Analysis of the effect of solar azimuth was determined for all smolt in proximity to the fixed instruments using 2 categories: easterly solar azimuth and westerly solar azimuth. Analysis of the effect of salinity gradient was determined for smolt in proximity to CTD 1 using 2 categories: a negative salinity gradient (salinity at CTD 1 greater than at CTD 2), and a positive salinity gradient (salinity at CTD 2 greater than at CTD 1). Salinity data from CTDs 1 and 2 were used for analyzing the effect of salinity because they were in close proximity, so it could be assumed that a gradient detected between these 2 instruments would exist within the space separating them. For both analyses of the effect of azimuth and the effect of salinity gradient, the sample size was greatly reduced (only daylight hours were used for analyzing the effect of azimuth and only smolt data from CTD 1 were used for analyzing the effect of salinity gradient), so it was not possible to examine interaction effects with other environmental properties.

\section{RESULTS}

\section{Interpolation of smolt centres of activity}

Boat-mounted transmitter transits within the inner bay, as recorded by the onboard GPS, were similar to those predicted using the running-line smoother method. No significant difference existed between the observed and estimated coordinates for either the easting (correlation test, $t_{1630}=475.38, \mathrm{p}<0.001, \mathrm{r}=$ 0.99 ) or the northing (correlation test, $t_{1630}=181.59, \mathrm{p}<$ $0.001, r=0.97$ ), and no significant difference existed between observed and estimated velocities for either the $x$-component (correlation test, $t_{1629}=41.74, \mathrm{p}<$ $0.001, \mathrm{r}=0.71$ ) or the $y$-component (correlation test, $\left.t_{1629}=34.86, \mathrm{p}<0.001, \mathrm{r}=0.65\right)$. This was a large improvement on estimates from the weighted-mean approach: $\mathrm{r}=0.84$ (northing), $\mathrm{r}=0.4686$ (easting), $\mathrm{r}=$ 0.0100 (velocity $x$-component), and $r=-0.0046$ (velocity $y$-component). 


\section{Surface currents and salinity in Gaspé Bay}

Buoy displacements in 2005 showed a complex circulation pattern dominated by eddies at multiple spatial and temporal scales. The difference in speeds and angular deviations of pairs of buoys increased as a function of separation distance. At separation distances of less than $400 \mathrm{~m}$, current speeds were similar (correlation test, $t_{33}=$ 13.10, $\mathrm{p}<0.001, \mathrm{r}=0.91$ ). At separation distances of several km, correlations were never greater than 0.35 . Angular deviations from the buoy measurements were consistently less than $20^{\circ}$ at separation distances of less than $400 \mathrm{~m}$, but increased rapidly at greater distances. As evident from the fixed instruments in 2006, currents were heterogeneous over short temporal scales (Fig. 2). The relationship between current flows and tidal and wind forcing was relatively weak, although major changes in wind direction were associated with major changes in current direction. Autocorrelation functions showed distinct periodicities at the ADCP and RCM 1, which were similar to those of the periodicity in tidal gradient, suggesting that tidal forcing affected the residual current

Surface salinity varied greatly both spatially and temporally (Fig 3). Across-bay gradients were found in both 2005 and 2006, but salinity patterns were dominated by fine-scale heterogeneity. Across-bay gradients were weak in 2006 and a gradient of increasing salinity from CTD 1 to CTD 2 did not always exist. Autocorrelation functions showed a salinity periodicity in CTDs 1 and 3, suggesting a tidal effect. Salinity was greater during inflowing currents (23.52 PSU) at CTD 1 than during outflowing currents (22.28 PSU) ( $t$-test, $t_{2076}=12.97, \mathrm{p}<$ 0.001). This effect was not apparent at CTD 2 or CTD 3, which appeared to be more subject to eddying. Mean surface salinity greatly differed between 2005 and 2006. Through the period of sampling in 2005, no consistent temporal trend in salinity occurred (mean salinity in the inner bay was 14.84 PSU), whereas for 2006, mean salinity measured by the CTDs was 6.39 PSU prior to 22 May, but was 22.77 PSU from 22 May to 30 June. The increase in surface salinity occurred in less than a day. During the period of increase, the difference in salinity between CTD 2 and CTD 1 increased markedly, suggesting that there was an intrusion of saline water into the inner bay.

\section{Synoptic pattern of smolt migration}

A total of 6292 and 19434 recordings were made by the hydrophone array in 2005 and 2006, respectively. The mean number of recordings per smolt per
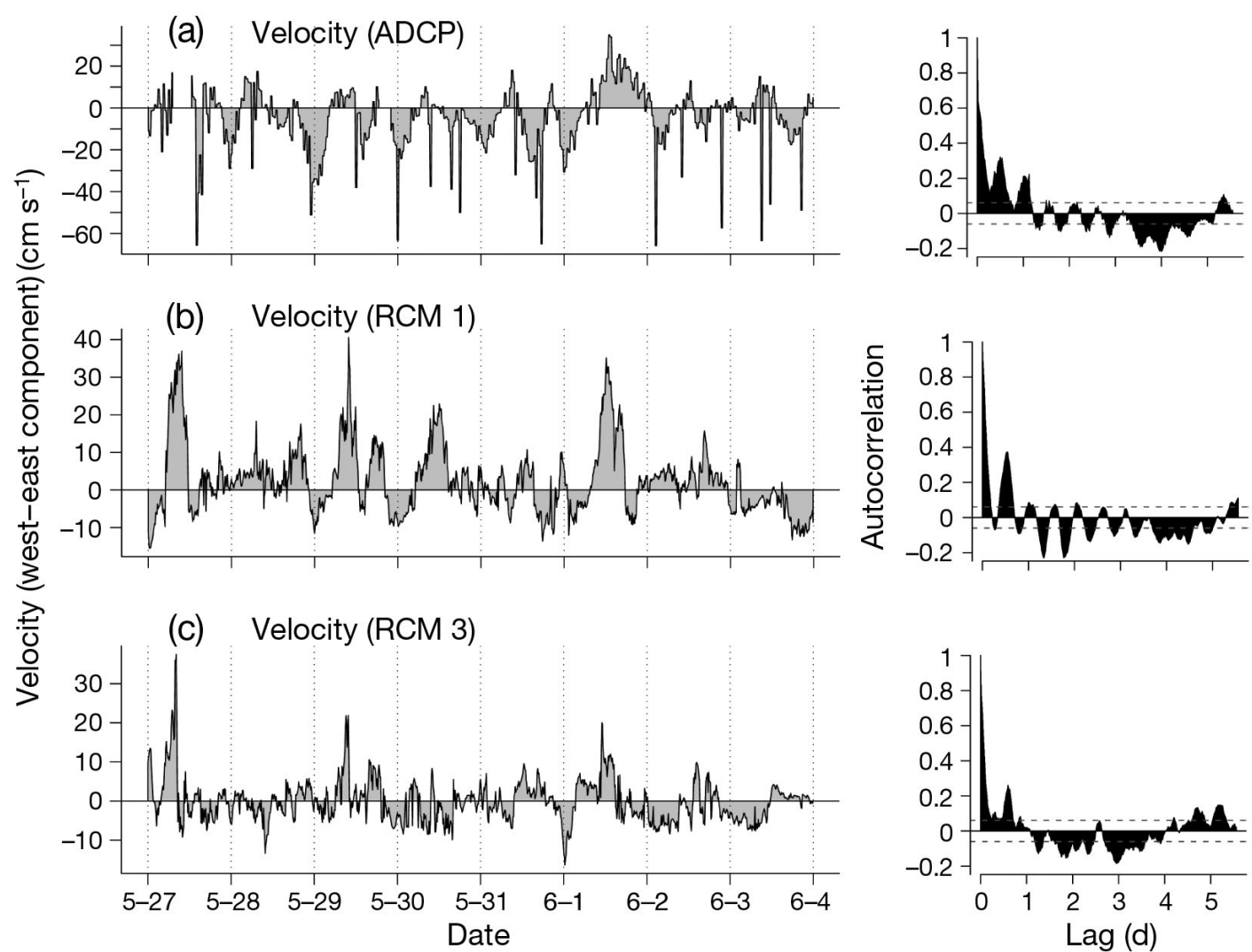

Fig. 2. Time-series and autocorrelation functions of current velocity: (a) current velocity (west-east component) at ADCP; (b) current velocity (west-east component) at RCM 1; (c) current velocity (west-east component) at RCM 3. Dates (2006) are given as mo-d 

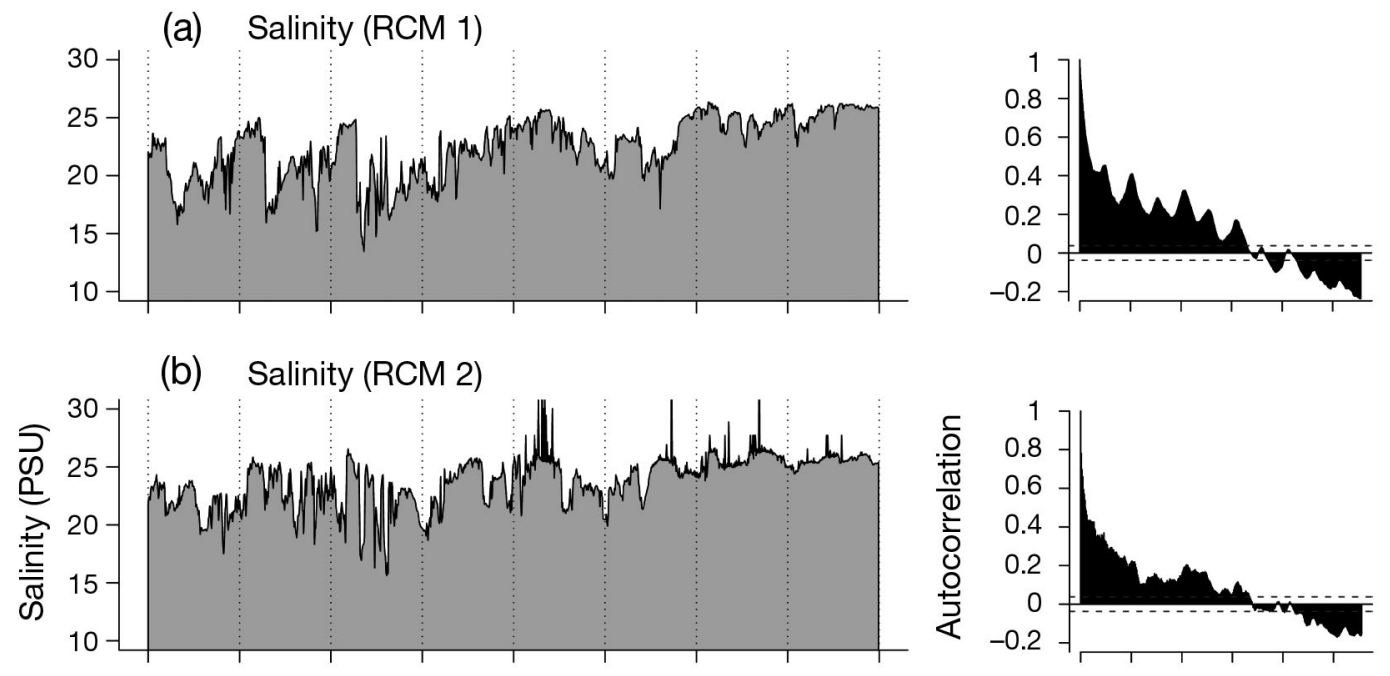

(c) Salinity (RCM 3)
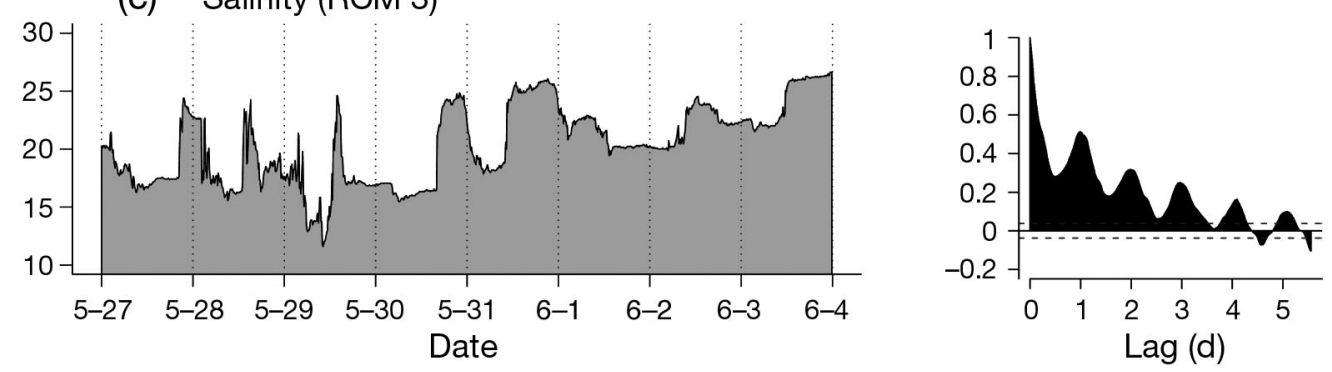

Fig. 3. Time-series and autocorrelation functions of surface salinity: (a) salinity at RCM 1; (b) salinity at RCM 2; (c) salinity at RCM 3. Dates (2006) are given as mo-d

hydrophone was 9.46 and 14.10 in 2005 and 2006, respectively; this difference may be attributed to the denser array deployed in 2006. Of the 24 smolt released in 2005 and 30 smolt released in 2006, 14 and 27 smolt, respectively, migrated from York Estuary to the inner bay. Of the smolt that entered the inner bay, 2 smolt in 2006 were not registered by the hydrophone array in the outer bay. There was a wide variation in the migration pattern through the inner bay (Fig. 4). The most common method of migration between the inner and outer bay was through the channel: of the 39 smolt that migrated from the inner to the outer bay, 34 used the channel while 5 crossed the sandbar at high tide. For those migrating through the channel, the initial pattern was approximately evenly split between smolt that took a direct route (13 smolt) and smolt that initially migrated towards the sandbar before deviating towards the channel (14 smolt), with a smaller number of smolt taking a more complex route $(7$ smolt). Tidal elevation appeared to have an effect on the route that smolt were able to take: if the smolt initially migrated towards the sandbar, they were only able to cross it to the outer bay under conditions of high tide; if they arrived at the sandbar at low tide, they were forced to deviate either northward or southward.

Smolt residence time in the inner bay in 2005 (mean $=0.96 \mathrm{~d}$; range $=0.27$ to $2.03 \mathrm{~d}$ ) was significantly greater than in 2006 (mean $=0.45 \mathrm{~d}$; range $=0.13$ to $2.08 \mathrm{~d}$ ) ( $t$-test, $t_{17.25}=2.51, \mathrm{p}=0.02$ ) (Fig. 5). The direction of displacement of the smolt population in the inner bay in 2006 was significantly more focussed outward than in 2005 (circular ANOVA $F$-test, $F_{1,3193}=$ 133.6, $\mathrm{p}<0.001$ ) (Fig. 5). There was no significant effect of smolt size on migration.

For the smolt from 2005 and 2006 that passed through both the inner and outer bay, smolt direct-line ground speed in the inner bay (mean $=15.2 \mathrm{~cm} \mathrm{~s}^{-1}$ ) was significantly slower than in the outer bay (mean = $\left.27.5 \mathrm{~cm} \mathrm{~s}^{-1}\right)\left(t\right.$-test, $\left.t_{64.66}=-3.99, \mathrm{p}<0.001\right)$. A yearly effect was apparent in the inner bay. Smolt migration direct-line speed in the inner bay in 2005 (mean = $8.9 \mathrm{~cm} \mathrm{~s}^{-1}$ ) was significantly slower than in 2006 (mean $\left.=18.5 \mathrm{~cm} \mathrm{~s}^{-1}\right)\left(t\right.$-test, $\left.t_{35.53}=-3.40, \mathrm{p}=0.001\right)$. No significant difference existed in direct-line speed between years in the outer bay $\left(2005\right.$, mean $=26.6 \mathrm{~cm} \mathrm{~s}^{-1} ; 2006$, mean $\left.=28.0 \mathrm{~cm} \mathrm{~s}^{-1}\right)\left(t\right.$-test, $\left.t_{16.21}=-0.21, \mathrm{p}=0.8338\right)$. 


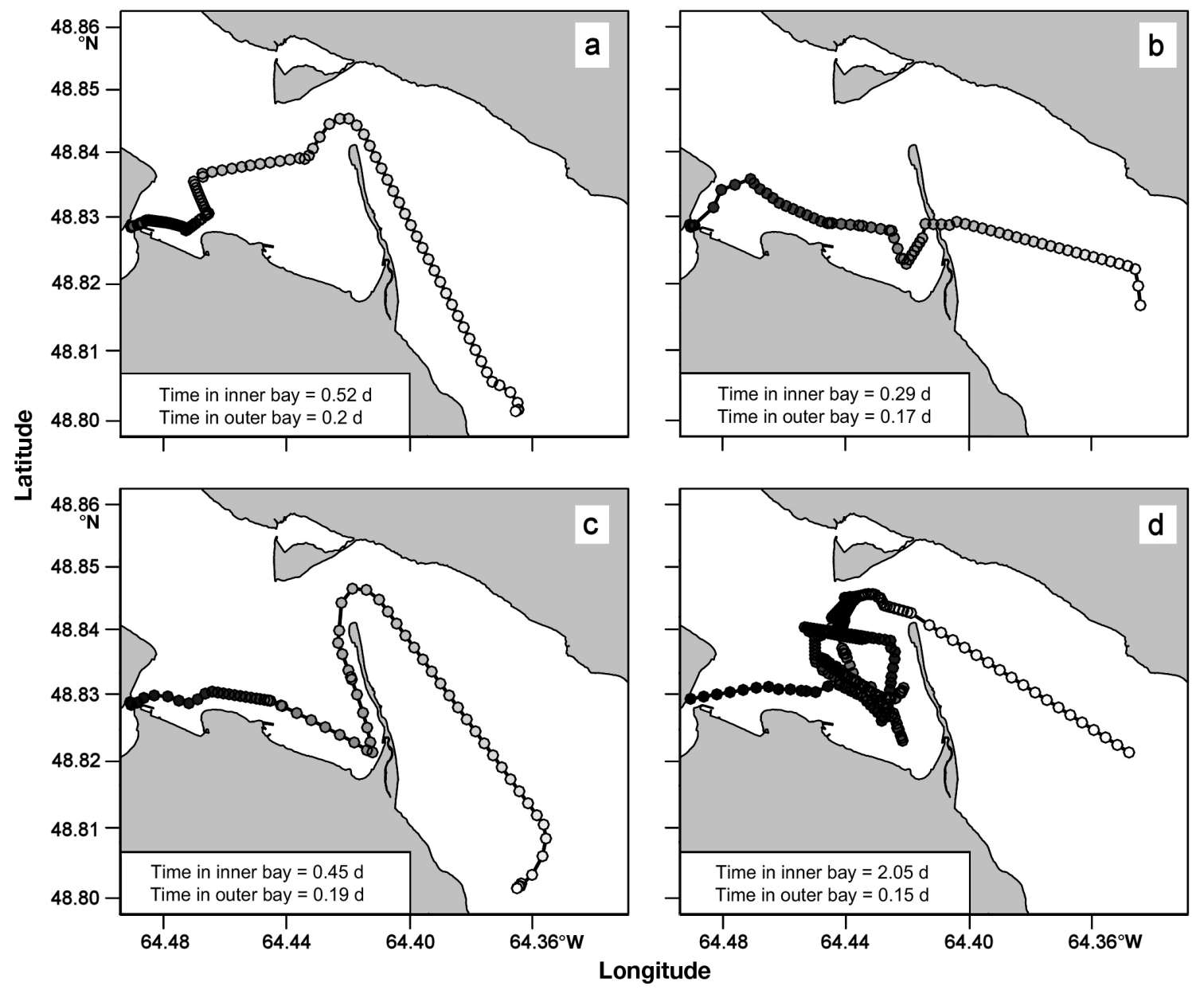

Fig. 4. Salmo salar. Examples of smolt migration patterns in 2006: (a) rapid migration through the channel; (b) rapid migration over the sandbar at high tide; (c) initial migration to the sandbar and deviation towards the channel; (d) slow migration
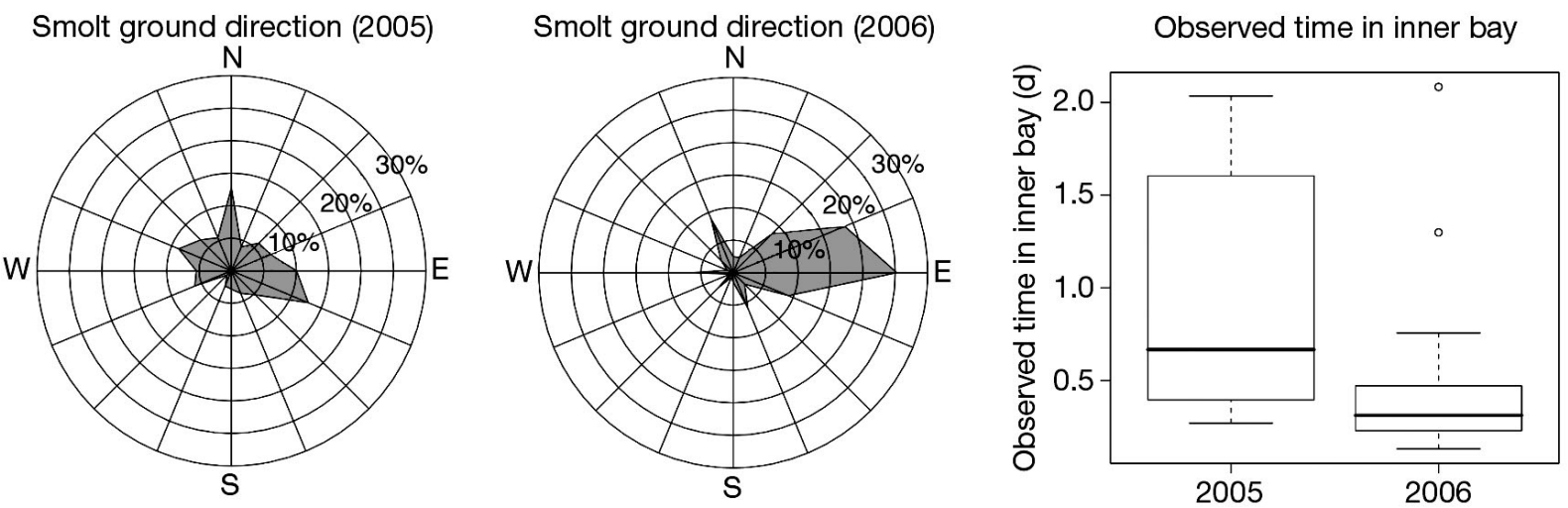

Fig. 5. Salmo salar. Smolt migration in the inner bay in 2005 and 2006. In this and all subsequent figures using wind-rose plots to display direction, percentage composition has been divided into units of $22.5^{\circ}$ centred at $\mathrm{N}, \mathrm{NNE}, \mathrm{NE}, \mathrm{ENE}, \mathrm{E}, \mathrm{ESE}, \mathrm{SE}, \mathrm{SSE}, \mathrm{S}$, SSW, SW, WSW, W, NNW, NW. Percentage compositions are shown by the reference circumferences: e.g. smolt ground direction in 2006 has $25 \%$ composition in an eastward direction. Smolt that disappeared while in the inner bay (either through predation, transmitter failure or avoidance of the hydrophone array) have been excluded. Box plot: thick line: median; box: 1st to 3rd quartiles; whiskers: all values outside box within $1.5 \times$ interquartile range 

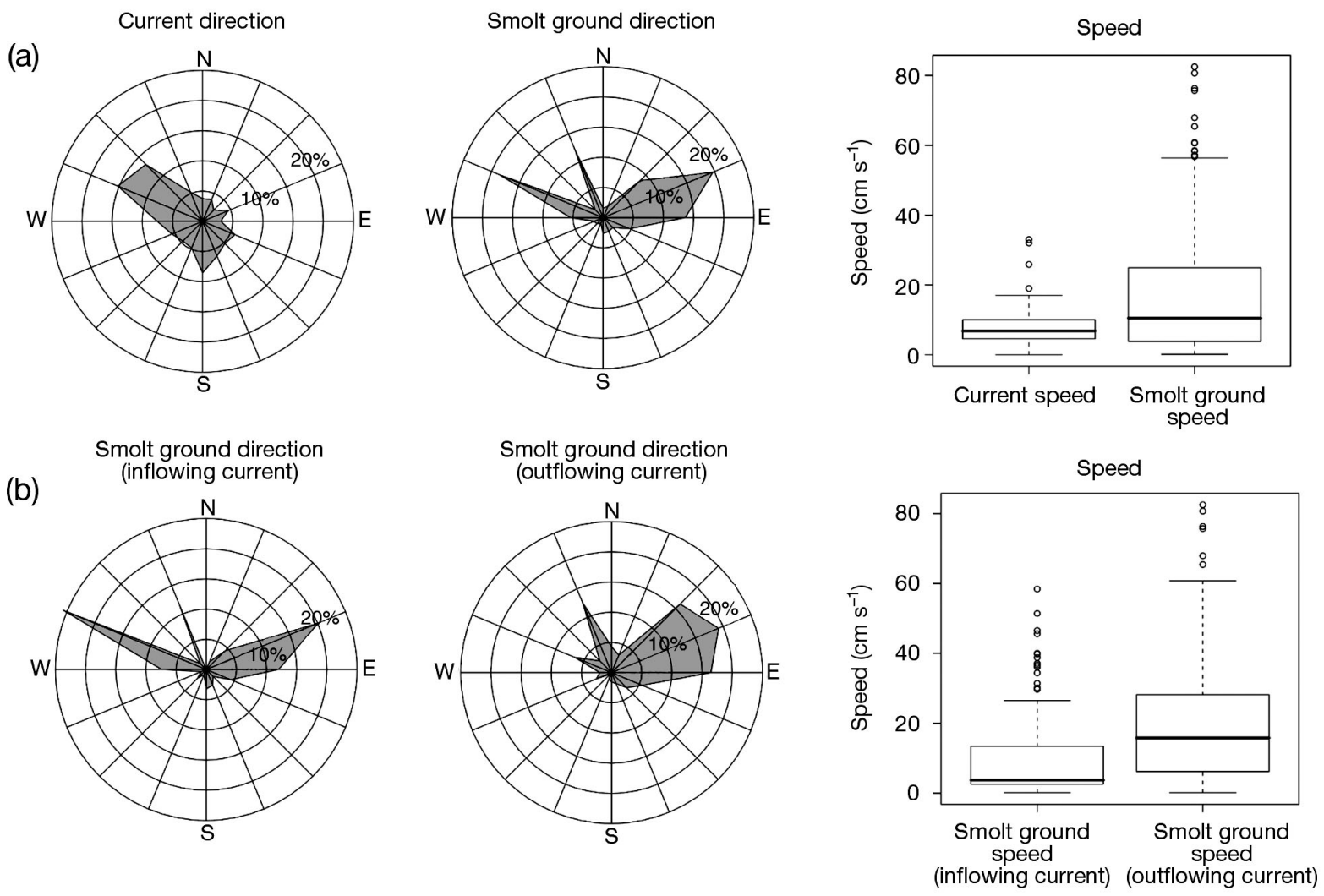

Fig. 6. Salmo salar. Relationship between smolt migration and current flow in the proximity of the fixed instruments (ADCP, RCM 1 and RCM 3): (a) direction and speed of currents and smolt; (b) direction and speed of smolt under inflowing currents and outflowing currents. Box plots as in Fig. 5

\section{Passive versus active migration and mechanisms of orientation}

Throughout the time when smolt were within a range of $400 \mathrm{~m}$ of the fixed instruments, there was clear evidence of active migration. The main current direction in the inner bay was inward, whereas smolt showed a bimodal migration pattern with both inward and outward migration (Fig. 6a). This difference was statistically significant (Table 1). Mean smolt ground speed (16.4 $\mathrm{cm} \mathrm{s}^{-1}$ ) was also significantly greater than mean current speed $\left(7.5 \mathrm{~cm} \mathrm{~s}^{-1}\right)$, suggesting an active component to the migration. Smolt migrated in both an inward and an outward direction during inflowing currents, but smolt migration was almost entirely outward during outflowing currents (Fig. 6b). This difference was statistically significant (Table 1). Mean ground speed during outflowing currents $\left(19.9 \mathrm{~cm} \mathrm{~s}^{-1}\right)$ was significantly greater than mean ground speed during inflowing currents $\left(10.6 \mathrm{~cm} \mathrm{~s}^{-1}\right)$.

Smolt swimming direction was mainly outward (towards the northeast and east) (Fig. 7). Swimming direction and speed were dependent on current direction and the presence/absence of daylight (Fig. 8, Table 2). Swimming direction was strongly focussed outward during inflowing currents during night; during other times, swimming direction was much less focussed. Swimming was faster during the day $\left(21.2 \mathrm{~cm} \mathrm{~s}^{-1}\right.$ during inflowing currents, $22.5 \mathrm{~cm} \mathrm{~s}^{-1}$ during outflowing currents) than the night $\left(14.4 \mathrm{~cm} \mathrm{~s}^{-1}\right.$ during inflowing currents, $13.7 \mathrm{~cm} \mathrm{~s}^{-1}$ during outflowing currents).

Table 1. Statistical comparisons of currents and smolt ground movement. Sample size for the analysis of the effect of speed is less than that for direction because RCM 2 only provided data on current direction and not speed (due to the failure of its speedometer)

\begin{tabular}{|c|c|c|c|c|c|c|}
\hline \multirow{2}{*}{ Comparison } & \multicolumn{2}{|c|}{ - Sample size -} & \multicolumn{2}{|c|}{$\longrightarrow$ Direction -} & \multicolumn{2}{|c|}{- Speed } \\
\hline & Direction & Speed & Circular ANOVA & $\mathrm{p}$ & $t$-test & $\mathrm{p}$ \\
\hline Current vs. smolt ground movement & 1380 & 698 & $F_{1,1378}=469.8$ & $<0.001$ & $t_{413}=-9.74$ & $<0.001$ \\
\hline (inflowing vs. outflowing current) & 687 & 348 & $F_{1,685}=39.57$ & $<0.001$ & $t_{337}=-5.82$ & $<0.001$ \\
\hline
\end{tabular}




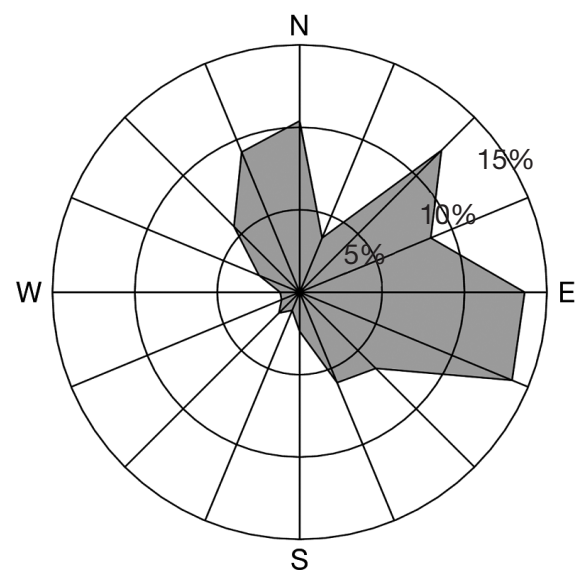

Fig. 7. Salmo salar. Direction of smolt swimming in the proximity of the fixed instruments (ADCP, RCM 1 and RCM 3)
Table 2. Statistical comparisons of smolt swimming under different environmental conditions. Current direction: inflowing vs. outflowing; time of day: night vs. day. A negative salinity gradient refers to the condition where the salinity at CTD 1 is greater than at CTD 2; a positive salinity gradient refers to the condition where the salinity at CTD 2 is greater than at CTD 1

\begin{tabular}{|c|c|c|c|c|c|}
\hline \multirow[t]{2}{*}{ Comparison } & \multirow{2}{*}{$\begin{array}{l}\text { Sample } \\
\text { size }\end{array}$} & \multicolumn{2}{|c|}{ Direction } & \multicolumn{2}{|c|}{ Speed } \\
\hline & & $\begin{array}{l}\text { Circular } \\
\text { ANOVA }\end{array}$ & $\mathrm{p}$ & $\begin{array}{c}t \text {-test/ } \\
\text { ANOVA }\end{array}$ & $\mathrm{p}$ \\
\hline $\begin{array}{l}\text { Current direction } \\
\text { and time of day }\end{array}$ & & & & & \\
\hline $\begin{array}{l}\text { Inflowing, night } \\
\text { vs. outflowing, night } \\
\text { vs. inflowing, day } \\
\text { vs. outflowing, day }\end{array}$ & 341 & $F_{3,337}=26.39$ & $<0.001$ & $F_{3,337}=6.94$ & $<0.001$ \\
\hline Solar azimuth & & & & & \\
\hline Easterly vs. westerly & 135 & $F_{1,333}=0.20$ & 0.648 & $t_{120}=1.25$ & 0.213 \\
\hline Salinity gradient & & & & & \\
\hline Negative vs. positive & 148 & $F_{1,146}=3.99$ & 0.047 & $t_{99}=-2.94$ & 0.004 \\
\hline
\end{tabular}

No effect of solar azimuth was present, in either swimming direction or swimming speed (Fig. 9, Table 2). Salinity had a weak effect on swimming direction but a strong effect on swimming speed. Swimming direction during a positive salinity gradient was significantly different to swimming direction during a negative salinity gradient, but the general direction of swimming was outward under both conditions. Mean swimming speed was significantly greater when there was a positive salinity gradient $\left(16.8 \mathrm{~cm} \mathrm{~s}^{-1}\right)$ than when there was a negative salinity gradient $\left(11.1 \mathrm{~cm} \mathrm{~s}^{-1}\right)$.

\section{Swimming direction}

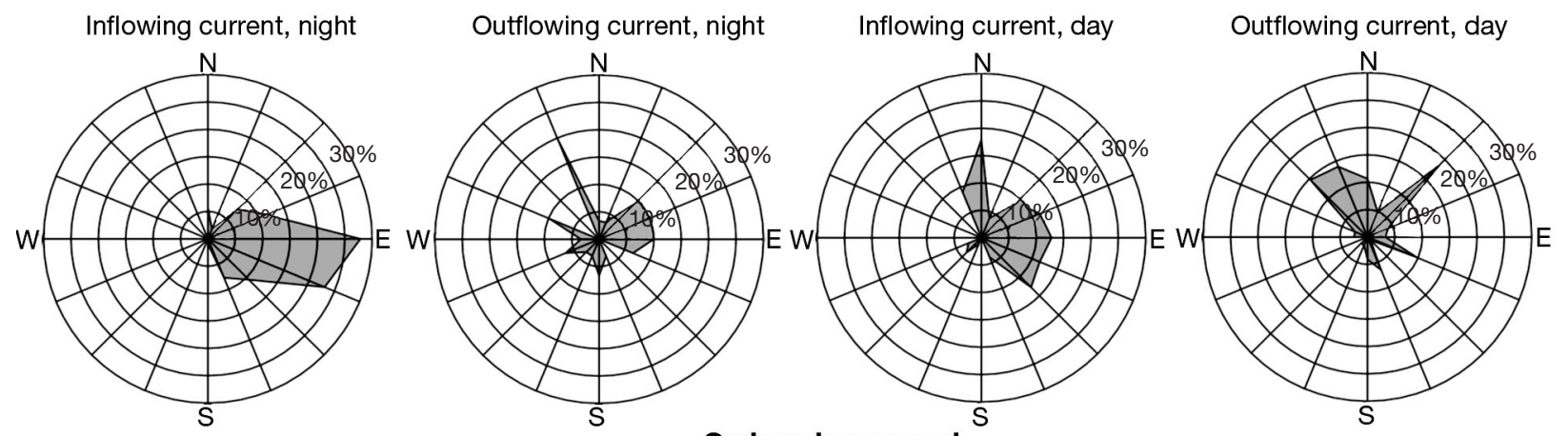

Swimming speed

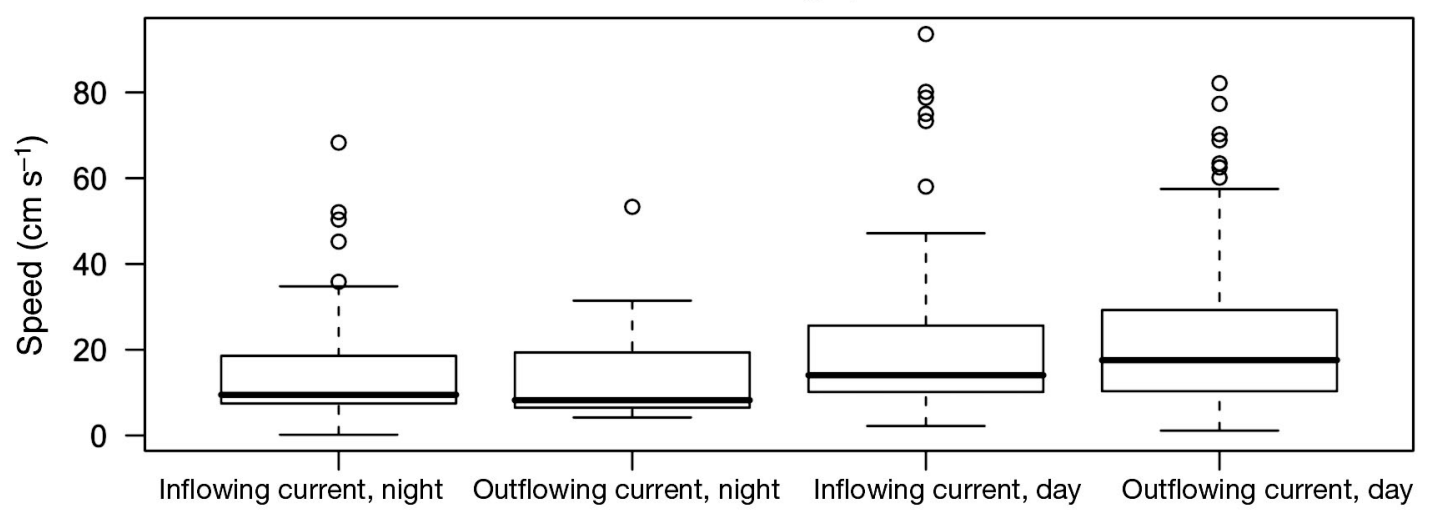

Fig. 8. Salmo salar. Relationship between smolt swimming direction and speed and current direction (inflowing vs. outflowing) and time of day (night vs. day). Box plots as in Fig. 5 
(a)

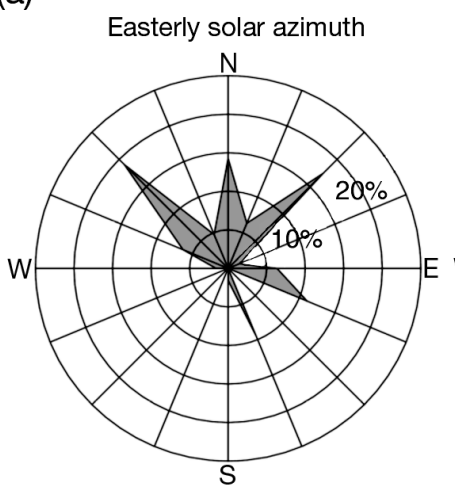

Swimming direction

(b)

\section{Swimming direction}

Negative salinity gradient (greatest salinity at CTD 1)
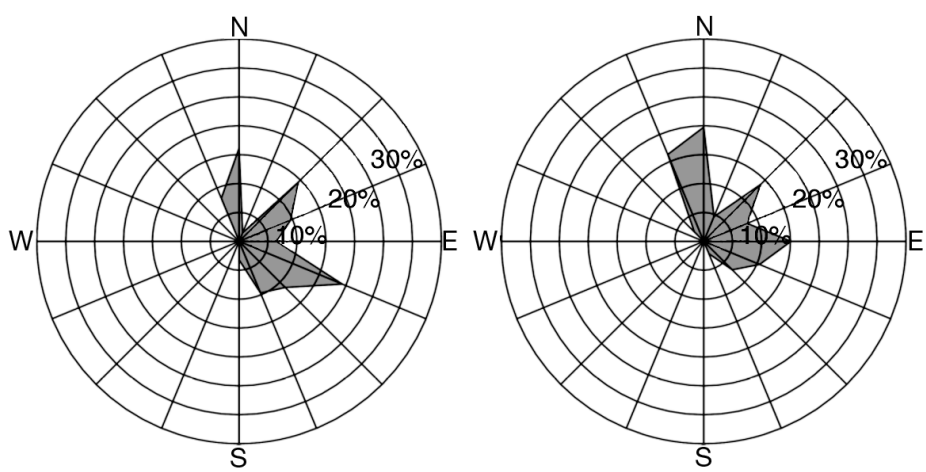

Westerly solar azimuth

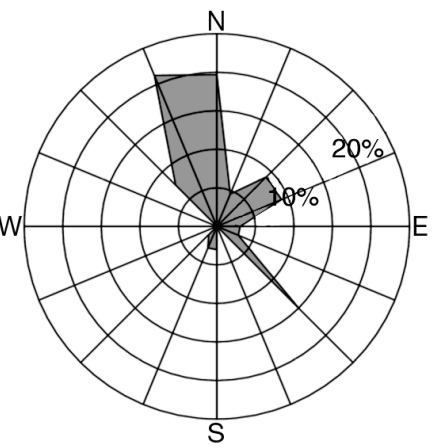

Positive salinity gradient Positive salinity gradient
(greatest salinity at CTD 2)

Fig. 9. Salmo salar. Relationship between smolt swimming direction and speed and (a) solar azimuth (easterly vs. westerly) and (b) salinity gradients (negative vs. positive salinity gradient). For solar azimuth effects, all data in proximity to the fixed instruments (ADCP, RCM 1 and RCM 3) are used; for salinity gradient effects, only swimming data from smolt in proximity to CTD 1 are used. Box plots as in Fig. 5

\section{DISCUSSION}

The present study used an array of fixed hydrophones to determine migration patterns of Atlantic salmon smolt over a finer spatial scale than that of previous studies, providing new insights on fish migration. This fine resolution provided more accurate estimates of smolt swimming speeds because it increased the ability to measure changes in smolt position over fine spatial and temporal scales and detected movements that less dense arrays would have missed. For example, the mean direct-line ground speed of $15.2 \mathrm{~cm} \mathrm{~s}^{-1}\left(\mathrm{SD}=0.10 \mathrm{~cm} \mathrm{~s}^{-1}\right)$, estimated solely from detections of smolt at the entrance and exit of the inner bay, was less than the mean ground speed of $27.5 \mathrm{~cm}$ $\mathrm{s}^{-1}\left(\mathrm{SD}=0.15 \mathrm{~cm} \mathrm{~s}^{-1}\right)$ estimated using the running-line smoother algorithm with detections from all hydrophones in the inner bay. Additionally, the fact that hydrophones were in close enough proximity for smolt to often be detected at multiple hydrophones over short time scales meant that it was possible to predict smolt

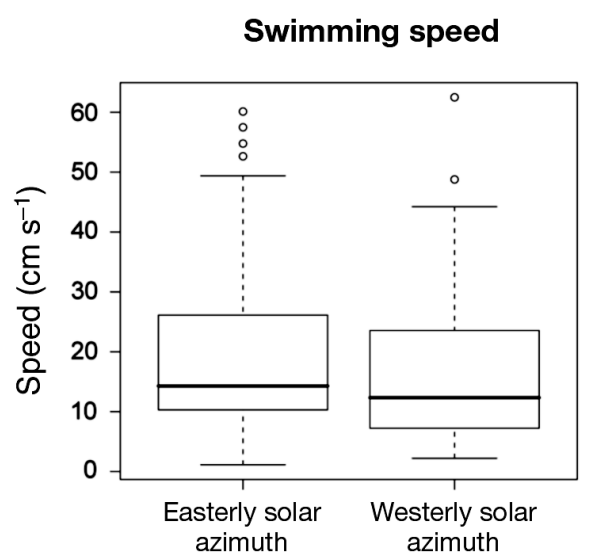

Swimming speed

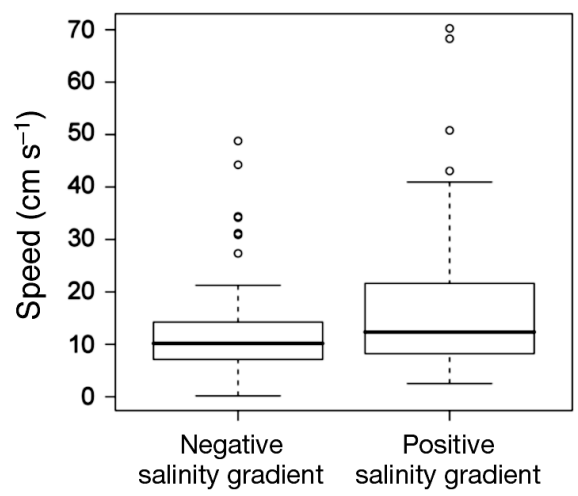


the relatively high rates of seaward migration in estuaries during the ebb tide found in previous studies (see Tytler et al. 1978, Aprahamian \& Jones 1997 , Moore et al. 1998). This by itself does not suggest passive migration; it merely means that smolt migration was aided by outflowing currents. Additionally, active migration was indicated by the fact that throughout the time that smolt were migrating outwards, the residual current was in an inwards direction.

Patterns of smolt swimming were clearly affected by the combined effects of currents, the presence/ absence of daylight, and salinity. Two patterns of swimming direction occurred: (1) swimming was focussed outward during nocturnal inflowing currents, and (2) a more diffuse pattern occurred during nocturnal outflowing currents and during the day (both during inflowing and outflowing currents). Inflowing currents were associated with an increase in salinity, so this was possibly a mechanism used for orientation. Although there was no indication of smolt exploiting celestial cues to achieve an outward orientation, a diurnal pattern of swimming speed was also apparent, with smolt swimming faster during the day but with a more dispersed directional distribution. Diurnal changes in smolt behaviour may have been related to foraging, which occurs mainly during the day as smolt require visual cues for detecting prey (Kadri et al. 1997) or avoiding predators (Jepsen et al. 2006). The pattern of smolt migration was, therefore, consistent with smolt migrating offshore nocturnally (which has been reported by Aprahamian \& Jones 1997, Moore et al. 1998), using increases in salinity on inflowing currents for orientation, and using daytime hours for prey detection and predator avoidance.

Swimming speed was significantly related to salinity gradient, with smolt swimming speed increasing under conditions of a positive salinity gradient (salinity increasing away from CTD 1 towards CTD 2). This suggests that smolt were responding to salinity, actively swimming towards saline areas. This is the first time that a salinity gradient effect has been identified as a factor affecting active migration of smolt in water bodies when a strong salinity gradient is absent. The importance of salinity was also substantiated by the observation that migration was faster in (1) the more saline water of the outer bay than in the fresher waters of the inner bay and (2) the more saline waters of the inner bay in 2006 than in 2005 (resulting in the shorter mean residence time in 2006).

Smolt migration was shown to be a largely active process, with smolt swimming outward even though the residual current was inward. Although significant relationships existed between patterns of smolt migration/swimming and environmental properties, it was not conclusively shown that these properties alone were responsible for smolt orientation. For example, smolt actively swam against inflowing currents but did not actively swim against outflowing currents; smolt swam strongly against a positive salinity gradient but did not reverse their behaviour when there was a negative salinity gradient. These observations are consistent with the hypothesis that smolt exploit an innate compass to maintain a preferred bearing (reviewed in Dodson 1988).

In conclusion, Atlantic salmon smolt migrating from the York Estuary through Gaspé Bay demonstrated mainly active migration towards their offshore feeding grounds. The interplay between active migration and the demands of foraging remains to be clarified as does the nature of the compass mechanism underlying the migratory behaviour documented here. Exposure to more saline waters resulted in increased migration rates and exposure to positive salinity gradients resulted in greater swimming speed when fish were migrating outward. The high rate of displacement through the coastal zone afforded by active migration and rapid exposure to high salinities, even in the absence of persistent salinity gradients, should serve to accelerate the movement of smolt towards their offshore feeding grounds and minimize near-shore predation.

Acknowledgements. The study was funded by contributions from GEOIDE (GEOmatics for Informed DEcisions, a Canadian Centre of Excellence) the Ministère des Ressources Naturelles et de la Faune du Québec, the Atlantic Salmon Federation, the Centre collégial de transfert de technologie des pêches (CCTTP-CSP, Grande Rivière), the Fondation pour le saumon du Grand Gaspé, ALCAN Inc., and QuébecOcéan. We thank P. Brooking and G. Doucette of the Atlantic Salmon Federation for providing equipment and assistance in the realization of this project. We are grateful to D. Fournier, V. Cauchon, and J. F. Bourque for their assistance in the field. Also, for kindly familiarizing us with the York River and giving us access to fishing pools, we thank J. Roy of the Société de gestion des rivières du Grand Gaspé. Finally, we thank the students who helped us in the field: O. Deshaies, T. Garneau, N. Harnois, M. Lalonde, J. Lapointe, J. Leclère, A. Remy, A. Richard, and E. Valiquette. This is a contribution to the programme of GEOIDE and CIRSA (Centre Interuniversitaire de Recherche sur le Saumon Atlantique).

\section{LITERATURE CITED}

Aprahamian MW, Jones GO (1997) The seaward movement of Atlantic salmon smolts in the Usk estuary, Wales, as inferred from power station catches. J Fish Biol 50: 442-444

Batschelet E (1965) Statistical methods for the analysis of problems in animal orientation and certain biological rhythms. American Institute of Biological Sciences, Washington, DC

Becker RA, Chambers JM, Wilks AR (1988) The New S Language: a programming environment for data analysis and 
graphics. Wadsworth and Brooks/Cole Advanced Books \& Software, Monterey, CA

Blackwell BF, Juanes F (1998) Predation on Atlantic salmon smolts by striped bass after dam passage. N Am J Fish Manage 18:936-939

Carrière JB (1973) A physical oceanographic study of the Havre and Baie de Gaspé. MSc thesis, Dalhousie University, Halifax

Dieperink C, Bak BD, Pedersen LF, Pedersen MI, Pedersen S (2002) Predation on Atlantic salmon and sea trout during their first days as postsmolts. J Fish Biol 61:848-852

Dodson JJ (1988) The nature and role of learning in the orientation and migratory behavior of fishes. Environ Biol Fish 23:161-182

Dutil JD, Coutu JM (1988) Early marine life of Atlantic Salmon, Salmo salar, postsmolts in the northern Gulf of StLawrence. Fish Bull 86:197-212

Finstad B, Økland F, Thorstad EB, Bjorn PA, McKinley RS (2005) Migration of hatchery-reared Atlantic salmon and wild anadromous brown trout post-smolts in a Norwegian fjord system. J Fish Biol 66:86-96

Godin G (1988) Tides. Anadyomene Edition, Ottawa

Holm M, Huse I, Waatevik E, Doving KB, Aure J (1982) Behaviour of Atlantic salmon smolts during seaward migration. I. Preliminary report on ultrasonic tracking in a Norwegian fjord system. ICES CM 1982/M:7

Holm M, Holst JC, Hansen LP (2000) Spatial and temporal distribution of post-smolts of Atlantic salmon (Salmo salar L.) in the Norwegian Sea and adjacent areas. ICES J Mar Sci 57:955-964

Holm M, Holst JC, Hansen LP, Jacobsen JA, O'Maoliléidigh N, Moore A (2003) Migration and distribution of Atlantic salmon post-smolts in the North Sea and North-East Atlantic. In: Mills D (ed) Salmon at the edge. Blackwell Science Publications, Oxford, p 7-23

Jepsen N, Holthe E, Økland F (2006) Observations of predation on salmon and trout smolts in a river mouth. Fish Manag Ecol 13:341-343

Kadri S, Metcalfe NB, Huntingford FA, Thorpe JE (1997) Daily feeding rhythms in Atlantic salmon. II: Size-related variation in feeding patterns of post-smolts under constant environmental conditions. J Fish Biol 50:273-279

Klimley AP, Le Boeuf BJ, Cantara KM, Richert JE, Davis SF, Van Sommeran S (2001) Radio acoustic positioning as a tool for studying site-specific behavior of the white shark and other large marine species. Mar Biol 138:429-446

Koutitonsky VG, Bugden GL (1991) The physical oceanography of the Gulf of St. Lawrence: a review on the synoptic variability of motion. In: Therriault JC (ed) The Gulf of St. Lawrence: small ocean or big estuary? Can Spec Publ Fish Aquat Sci 113:57-90

Koutitonsky VG, Desrosiers G, Pelletier E, Zakardjian B and others (2001) Études hydrodynamique, sédimentologique et benthique pour le choix de sites de mariculture d'omble de fontaine dans la baie de Gaspé. Institut des sciences de la mer de Rimouski, Rimouski

Lacroix GL, Knox D, Stokesbury MJW (2005) Survival and behaviour of post-smolt Atlantic salmon in coastal habitat with extreme tides. J Fish Biol 66:485-498

McCleave JD (1978) Rhythmic aspects of estuarine migration of hatchery-reared Atlantic salmon (Salmo salar smolts). J Fish Biol 12:559-570

Editorial responsibility: Howard Browman, Storebø, Norway
McCormick S, Hansen LP, Quinn TP, Saunders RL (1998) Movement, migration, and smolting of Atlantic salmon (Salmo salar). Can J Fish Aquat Sci 55:77-92

Moore A, Ives S, Mead TA, Talks L (1998) The migratory behaviour of wild Atlantic salmon (Salmo salar L.) smolts in the River Test and Southampton Water, southern England. Hydrobiologia 372:295-304

Moser ML, Olson AF, Quinn TP (1991) Riverine and estuarine migratory behavior of coho salmon (Oncorhynchuskisutch) smolts. Can J Fish Aquat Sci 48:1670-1678

Økland F, Thorstad EB, Finstad B, Sivertsgard R, Plantalech N, Jepsen N, McKinley RS (2006) Swimming speeds and orientation of wild Atlantic salmon post-smolts during the first stage of the marine migration. Fish Manag Ecol 13: $271-274$

Pettigrew B, Booth DA, Pigeon R (1991) Oceanographic observations in Havre de Gaspé during the Summer 1990. Canadian Data Report of Hydrography and Ocean Sciences 100, Ministère des Pêches et des Océans, MontJoli

Reddin DG, Short PB (1991) Postsmolt Atlantic salmon (Salmo salar) in the Labrador Sea. Can J Fish Aquat Sci 48:2-6

Reddin DG, Downton PD, Friedland KD (2006) Diurnal and nocturnal temperatures for Atlantic salmon postsmolts (Salmo salar L.) during their early marine life. Fish Bull 104:415-427

Rickardsen AH, Haugland M, Bjorn PA, Finstad B and others (2004) Geographical differences in marine feeding of Atlantic salmon post-smolts in Norwegian fjords. J Fish Biol 64:1655-1679

Shelton RGJ, Turrel WR, MacDonald A, Mclaren LS, Nicoll NT (1997) Records of post-smolt Atlantic salmon, Salmo salar L., in the Faroe-Shetland Channel in June 1996. Fish Res 31:159-162

Sherwin T (1988) Measurements of current speed using an Aanderaa RCM4 current meter in the presence of surface waves. Cont Shelf Res 8:131-144

Simpfendorfer CA, Heupel MR, Hueter RE (2002) Estimation of short-term centers of activity from an array of omnidirectional hydrophones and its use in studying animal movements. Can J Fish Aquat Sci 59:23-32

Stabell OB (1984) Homing and olfaction in salmonids - a critical-review with special reference to the Atlantic salmon. Biol Rev 59:333-388

Summerfelt RC, Smith LS (1990) Anesthesia, surgery, and related techniques. In: Schreck CB, Moyle PB (eds) Methods for fish biology. American Fisheries Society, Bethesda, MD, p 213-272

Taylor PB (1986) Experimental evidence for geomagnetic orientation in juvenile salmon, Oncorhynchus tschawytscha Walbaum. J Fish Biol 28:607-623

Thorstad EB, Økland F, Finstad B, Sivertsgard R, Bjorn PA, McKinley RS (2004) Migration speeds and orientation of Atlantic salmon and sea trout post-smolts in a Norwegian fjord system. Environ Biol Fish 71:305-311

Tytler P, Thorpe JE, Shearer WM (1978) Ultrasonic tracking of the movements of Atlantic salmon smolts (Salmo salar L.) in the estuaries of two Scottish rivers. J Fish Biol 12: 575-586

Voegeli FA, Lacroix GL, Anderson JM (1998) Development of miniature pingers for tracking Atlantic salmon smolts at sea. Hydrobiologia 371-2:35-46

Submitted: February 23, 2007; Accepted: September 5, 2007

Proofs received from author(s): January 31, 2008 